\title{
Evaluation of the Expansive Esna Shale and Its Role in the Deterioration of Heritage Buildings at West Bank of Luxor
}

\author{
Ahmed Fathi Younes Gelany¹, Mahmoud M. Abu Zeid², Mahmoud Sayed Abd El-Sadek ${ }^{3}$, \\ Abbas M. Mansour ${ }^{1}$ \\ ${ }^{1}$ Geology Department, Faculty of Science, South Valley University, Qena, Egypt \\ ${ }^{2}$ Civil Engineering Departments, Faculty of Engineering, South Valley University, Qena, Egypt \\ ${ }^{3}$ Nanomaterials Lab, Physical Department, Faculty of Science, South Valley University, Qena, Egypt \\ Email: mohammed20074@gmail.com
}

How to cite this paper: Gelany, A. F., Abu Zeid, M. M., Abd El-Sadek, M. S., \& Mansour, A. M. (2019). Evaluation of the Expansive Esna Shale and Its Role in the Deterioration of Heritage Buildings at West Bank of Luxor. Journal of Geoscience and Environment Protection, 7, 24-37.

https://doi.org/10.4236/gep.2019.78002

Received: June 14, 2019

Accepted: August 9, 2019

Published: August 12, 2019

Copyright $\odot 2019$ by author(s) and Scientific Research Publishing Inc. This work is licensed under the Creative Commons Attribution International License (CC BY 4.0).

http://creativecommons.org/licenses/by/4.0/

(c) (i) Open Access

\begin{abstract}
The heritage buildings at the west bank of Luxor were affected by expansive Esna shale differentially from site to others. The role of expansive Esna shale was evaluated by using X-ray diffraction spectra (particle size, strain), X-ray fluorescence, basic soil properties test, swelling test, soil classification, and unconfined compression test. Three different samples were examined to determine the expansive role in the deterioration of heritage sites. The expansive is high, according to: (a) Soil classification based on plasticity index, (b) Classification chart based on the liquid limit and plastic index, (c) Classification chart based on clay content and activity, (d) Soil classification, and (e) Swelling pressure which determines the safety factor. In addition, expansive classification assesses that Esna shale Formation is one of environmental hazards characterized by damage role near Nile flood and irrigation area and characterized by deterioration role in heritage sites far from Nile flood and irrigation area. This paper refers to evaluation as a main process of integrated conservation approach.
\end{abstract}

\section{Keywords}

Heritage, Deterioration, Expansive Soils, Integrated Approach

\section{Introduction}

Dupuis et al. (2011) refer to the genesis of tilted blocks in the Theban hills; they estimate the factors as the role of the Esna Shale and Tarawan Chalk, the action of the Nile river and tectonic thinning. The research area, located on the alluvial 
plains of the Nile Valley and surrounded by elevated structural plateaus capped by Eocene limestone, is underlain by Paleocene shale. The alluvial plains generally exhibit flat surfaces that gently slope northward. The average ground surface elevation is about $75.5 \mathrm{~m}$ above the mean sea level but rises to about $79 \mathrm{~m}$ at the fringes of the Nile Valley. The alluvial plains can be differentiated into (a) a densely cultivated younger plain occupying the central part of the Nile Valley and covered by Holocene silt and clay, and (b) an older reclaimed plain covered by Pleistocene sand and gravel (Abdellah, Gelany, \& Zeid, 2014; Ahmed, 2009; Ayman et al., 2016; El-Bayomi, 2007; Mahmoud, Kantiranis, \& Stratis, 2012).

In 1905, Bead Nell termed Esna shale to describe the unit at its type locality at Gebel Owaina opposite Esna city, northeast of Sebaiya. Esna shale Formation is divided into four distinct lithological units from top to base (Dupuis et al., 2011):

1) Abu Had (alternation of marl and limestone beds with a few clayey intervals. It is lighter in color and richer in carbonate than the underlying member).

2) Mahmiya member (dark clayey shale).

3) Dababiya Quarry member (dark grey shale from 0.6 to $3.7 \mathrm{~m}$ thick).

4) Hanady member (light grey massive shale).

Luxor heritage sites suffered from several environmental hazards during thousands of years since the pharaonic period till now. These hazards involve earthquakes, floods, dust storms, ... etc. Luxor western bank includes the greatest heritage sites in Egypt. Pharos constructed royal tombs and other buildings through three formations: the Tarawan Chalk, the Esna Shale, and the Thebes Limestone. The Esna Shale acts as soil foundation for five temples: Seti I, Ramses II, Habu, Amenhotep III, and Hatshepsut. Therefore, this Formation is the main stratigraphic unit in the archaeological sites at the western bank of Luxor. As shale is characterized by its expansive nature, especially with the occurrence of water from floods and other resources, it had a damaging effect and caused an environmental hazard.

This study aims to specify the characteristics of the expansive factor of the Esna Shale Formation using different methods such as swelling test, swelling potential, swelling pressure, in addition, discussion of the role of the expansive Esna Shale in the deterioration of archaeological buildings and sites. To achieve these goals, geological and geotechnical investigations were carried out, e.g. structural analysis, mineralogical composition, basic soil properties, swelling tests and classification of expansive soil according to (Ismaiel \& Badry, 2012). This will help in classifying and explaining the relation between all these soil geometers with the deterioration of heritage buildings in these greatest heritage sites. The study of the role of the Esna Shale Formation in the deterioration of archaeological sites is the basic step to evaluate the environmental hazards towards an integrated conservation approach. The Composite section of Luxor area is characterized by the occurrence of Quaternary and Holocene sediments. However, the Thebes Limestone and the Esna Shale formations are more distinct. Therefore, these heritage sites need primarily to be studied geologically 
and then to evaluate the character of the Esna Formation for the all-he western bank of the River Nile (opposite the Luxor town) includes the famous historical sites, so the category of expansive Esna Shale formation is essential for integrated conservation approach of these heritage sites.

To achieve our objectives, some investigations and analyses such as X-ray fluorescence spectrometer (XRF), X-ray diffraction pattern (XRD), free Swelling test, free swell index, and swelling pressure tests were carried out. These investigations and tests were applied to assess the role of the expansive. This study refers to evaluation as a main process of integrated conservation approach. The Expansive activity of the Esna Shale depends on the occurrence of water from different sources such as rains, Nile floods, especially before the high dam construction and agricultural activities. Although all these temples had been built over Esna shale Formation, the degradation and deterioration varied between Amenhotep III, Habu and Hatshepsut temples (Figure 1). Complete destruction of Amenhotep III Temple. The flooding region, irrigation canals and agriculture activity which were surrounded Amenhotep III Temple may be considered the main reason for raising the expansion activity of Esna shale, which resulted in complete damage for the mentioned temple.

On the other hand, Habu Temple is partially damaged because few irrigation canals and agricultural region were found on one side (in front of it). Hatshepsut Temple is located far from the irrigation and agricultural region so, there is a partial deterioration in the site. This means that increasing the activity of expansive Esna Shale Formation depends on the distance from water.

\section{Materials and Methodology}

\subsection{Samples of Esna Shale}

Esna shale samples used in this study are dark grey soil, which were collected from Esna shale Formation under Gebel Al Qurna, West bank of Luxor, Egypt. Three undisturbed fresh samples were obtained by open excavation (about $0.5 \mathrm{~m}$ depth). The three samples were brought near the temples 1) Amenhotep III temple, 2) Habu temple and 3) Hatshepsut temple respectively.

\subsection{Bulk Esna Shale Mineralogy}

Figure 2 shows XRD patterns of the three samples from three different locations at Luxor's west bank; 1) Amenhotep III temple, 2) Habu temple and 3) Hatshepsut temple.

XRD patterns of the three studied samples are nearly similar, reflecting the similarity of the mineral composition of these bulk samples. The bulk rock mineralogy of these shales include phylosilicates (smectite, smectite-illite mixed layer, illite and kaolinite) and non-clay minerals (quartz, calcite and feldspars). Smectite and smectite-illite mixed layers are the major minerals in these shales. These identified minerals are consistent with those reported by previous works (Abdal-Hay, Hamdy, Abdellah, \& Lim, 2014; Abou El-Anwar, EL-Wekeil, \& Gaafar, 


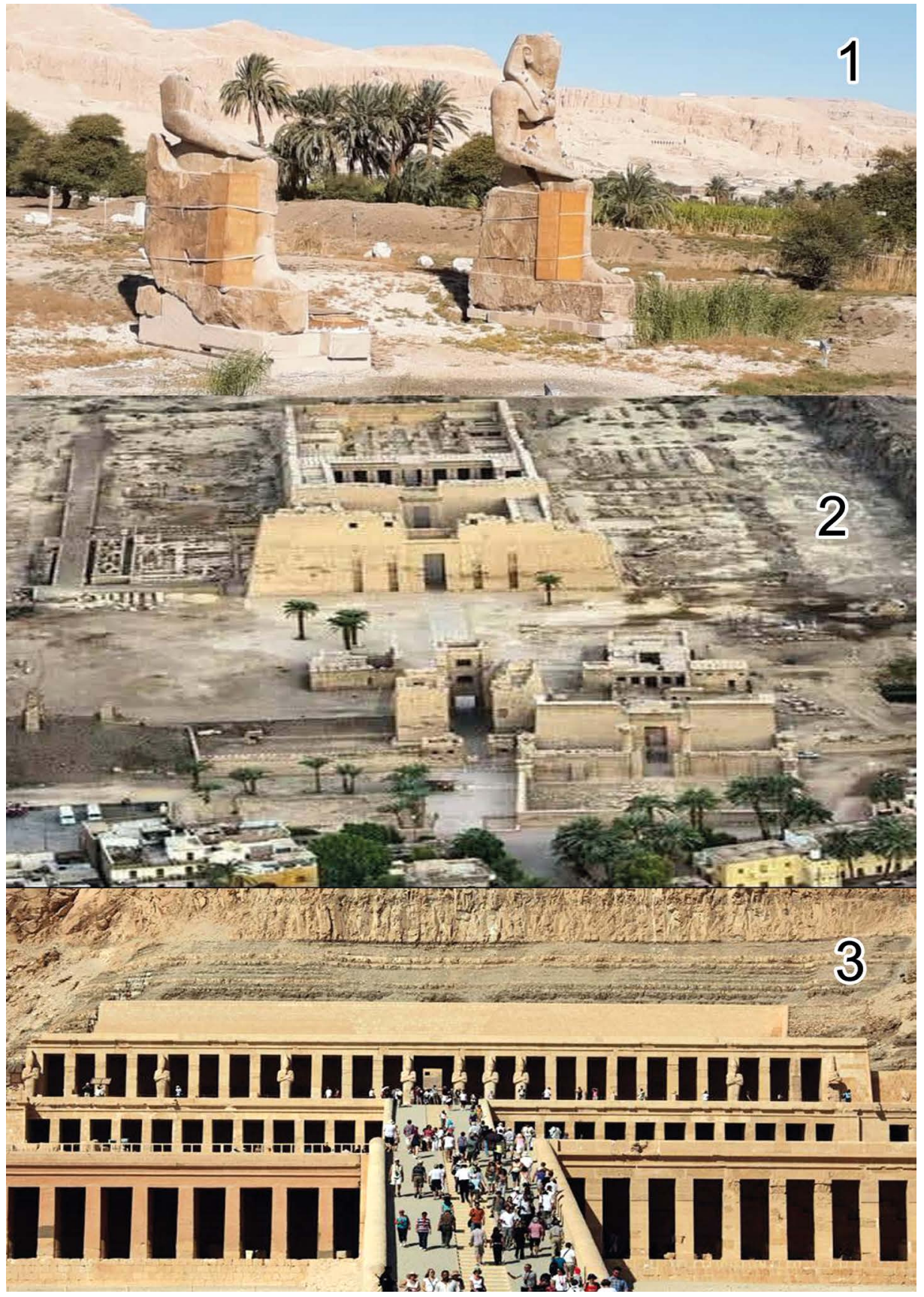

Figure 1. The degradation of deterioration from (a) Amenhotep temple, (b) Habu temple and (c) Hatshepsut temple, according to the divergence from the levels of the Nile flood and the irrigation area.

1819; Ibrahim, Rahim, Amat, Salehuddin, \& Ariffin, 2012; Mohammed, Hassan, \& Hashem, 2014; Temraz, 2005). Smectite and mectite-illite mixed layers Smectite are the principal reason for the expandability of these shales.

The results of (XRF) of the analyzed shale samples at the central lab. of the South Valley University illustrated the bulk major elements ( $\mathrm{Na}, \mathrm{Mg}, \mathrm{Al}, \mathrm{Si}, \mathrm{P}, \mathrm{S}$, $\mathrm{K}, \mathrm{Ca}, \mathrm{Ti}$, and $\mathrm{Fe}$ ) and a range of trace elements $(\mathrm{Mn}, \mathrm{V}, \mathrm{Cr}, \mathrm{Co}, \mathrm{Ni}, \mathrm{Cu}, \mathrm{Zn}, \mathrm{As}$, $\mathrm{Rb}, \mathrm{Sr}, \mathrm{Zr}, \mathrm{Nb}$, and $\mathrm{Mo}$ ). 


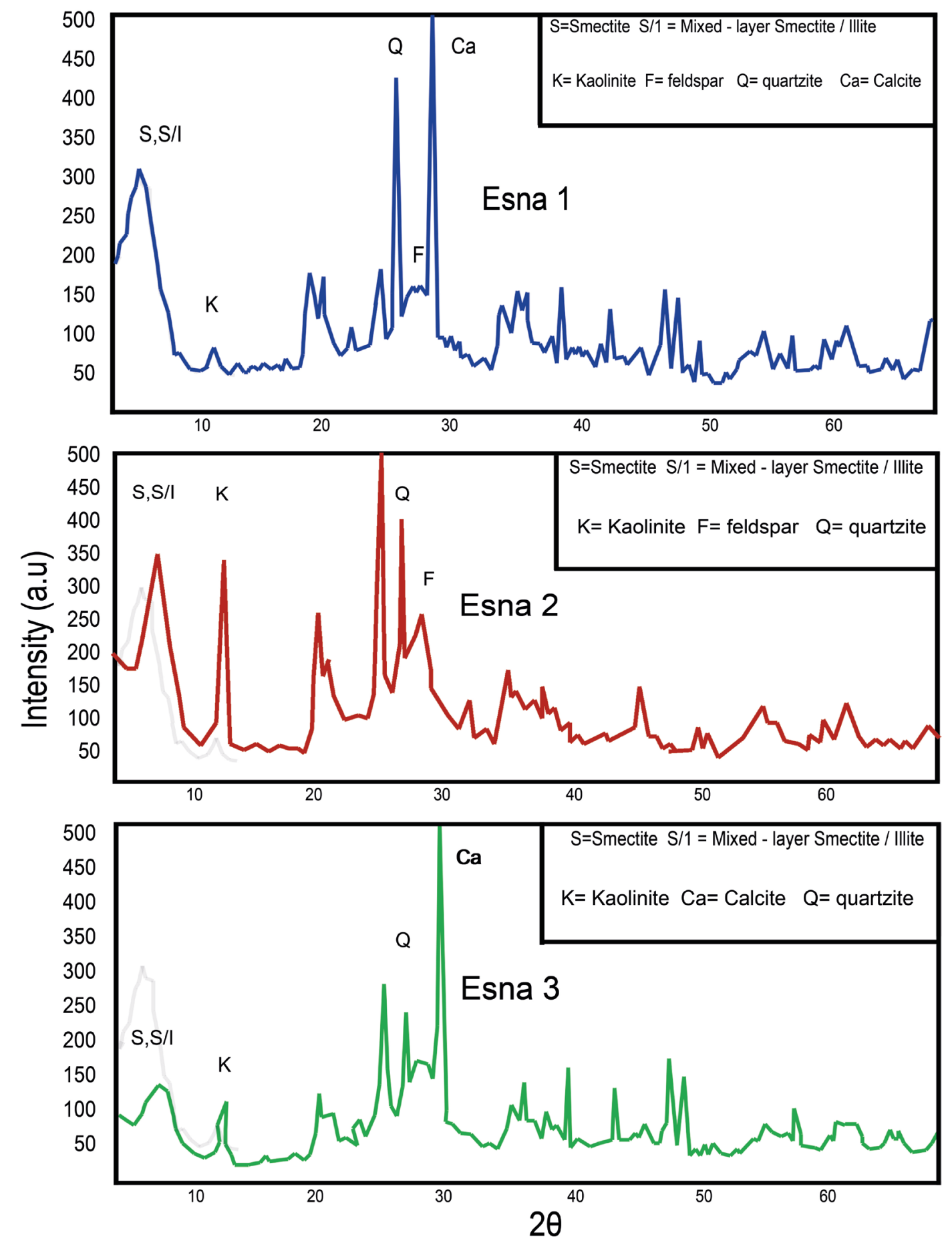

Figure 2. XRD patterns of the three Esna shales collected from El-Qurna area.

\subsection{FT-IR Analysis of Esna Shale}

Figure 3(a) and Figure 3(b) show FT-IR spectra for three Esna shale samples from near Amenhotep III temple (Figure 3(a)), from near Habu temple Figure 3 (b) and from near Hatshepsut temple (Figure 3(c)). The bands of IR spectra of the studied samples (Table 1) confirm the clay and non-clay minerals identified by XRD analysis. 


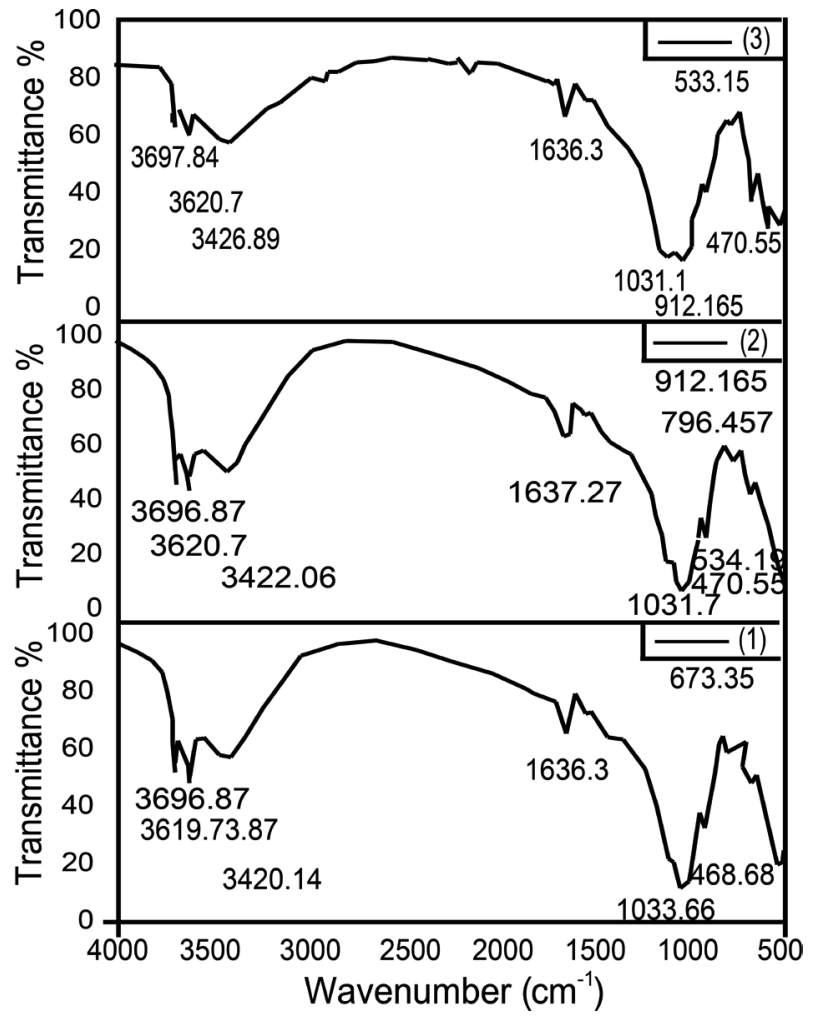

Figure 3. FT-IR spectra of Esna shales from three different locations.

Table 1. The wavenumber and the Functional groups OF Esna shale.

\begin{tabular}{|c|c|c|c|}
\hline $\begin{array}{l}\text { Wavenumbers, } \mathrm{cm}^{-1} \text { for } \\
\text { sample (1) }\end{array}$ & $\begin{array}{l}\text { Wavenumbers, } \mathrm{cm}^{-1} \text { for } \\
\text { sample (2) }\end{array}$ & $\begin{array}{l}\text { Wavenumbers, } \mathrm{cm}^{-1} \text { for } \\
\text { sample (3) }\end{array}$ & Type of Vibration \\
\hline $3697.84 \mathrm{~cm}^{-1}$ & $3696.87 \mathrm{~cm}^{-1}$ & $3696.87 \mathrm{~cm}^{-1}$ & $\begin{array}{l}\text { C- } \mathrm{H} \text { bond stretching (symmetric and asymmetric) } \\
\left(-\mathrm{CH}_{2} \text { and } \mathrm{CH}_{3}\right)\end{array}$ \\
\hline $3620.7 \mathrm{~cm}^{-1}$ & $3620.7 \mathrm{~cm}^{-1}$ & $3619.73 \mathrm{~cm}^{-1}$ & $\begin{array}{l}\mathrm{C}-\mathrm{H} \text { bond stretching (symmetric and asymmetric) } \\
\left(-\mathrm{CH}_{2} \text { and } \mathrm{CH}_{3}\right)\end{array}$ \\
\hline $3426.89 \mathrm{~cm}^{-1}$ & $3422.06 \mathrm{~cm}^{-1}$ & $3420.14 \mathrm{~cm}^{-1}$ & $\begin{array}{l}\text { The broad band around } 3354 \mathrm{~cm}^{-1} \text { can be assigned to } \\
\mathrm{O}-\mathrm{H} \text { and } \mathrm{N}-\mathrm{H} \text { stretching }\end{array}$ \\
\hline $1636.3 \mathrm{~cm}^{-1}$ & $1637.27 \mathrm{~cm}^{-1}$ & $1636.3 \mathrm{~cm}^{-1}$ & $\mathrm{C}=\mathrm{C}$ band \\
\hline $1031.1 \mathrm{~cm}^{-1}$ & $1031.7 \mathrm{~cm}^{-1}$ & $1033.66 \mathrm{~cm}^{-1}$ & $\begin{array}{l}\text { Corresponds to the production of silanol groups } \\
\text { ( } \mathrm{Si}-\mathrm{OH} \text { stretch) or } \mathrm{SiO}_{2} \text { impurity }\end{array}$ \\
\hline \multirow[t]{3}{*}{$912.165 \mathrm{~cm}^{-1}$} & $912.165 \mathrm{~cm}^{-1}$ & & Al-OH bending vibration \\
\hline & $796.457 \mathrm{~cm}^{-1}$ & & Which might be attributed to the intense twinning \\
\hline & & $673.035 \mathrm{~cm}^{-1}$ & $\mathrm{Si}-\mathrm{O}$ symmetrical bending vibration \\
\hline $535.15 \mathrm{~cm}^{-1}$ & $534.19 \mathrm{~cm}^{-1}$ & $536.114 \mathrm{~cm}^{-1}$ & Si-O-Al stretching \\
\hline $470.55 \mathrm{~cm}^{-1}$ & $470.55 \mathrm{~cm}^{-1}$ & $468.687 \mathrm{~cm}^{-1}$ & Si-O asymmetrical bending vibration \\
\hline
\end{tabular}

\subsection{Basic Shale Properties}

All tests on the studied samples were conducted according to the ASTM (American Society for Testing and Materials). Liquid and plastic limits tests, specific gravity, particle size distribution (mechanical method and hydrometer tech- 
nique), and swell potential tests were carried out according to ASTM 4318, ASTM D854, ASTM D421, ASTM D422 and ASTM D4546, respectively. The results of these tests are given in Table 2.

Modified Proctor test that was used to calculate dry density, free swelling test record a high result for swelling up to $150 \%$, which indicates to the danger of these areas from which the samples were taken. The grain size analysis illustrates the texture of these studied shales. The grain size analysis of these shales reveals that they are silty clay with $66 \%$ clay size, $31 \%$ silt size and $3 \%$ sand size. Figure 4 shows the plotting of the three studied on the liquid limit versus plastic index diagram where the three samples lie in the clay field. The plotting of the three samples were found in the clay part of diagram. Based on the intersection between the Liquid Limit (LL) and Plasticity Index (PI) on the plasticity chart, and the soil is classified as clay when Liquid Limit (LL) in the range $50 \%-60 \%$, and (PI) in the range $30 \%-40 \%$, so all samples classified as $\mathrm{CH}-$ High Plasticity Clay. (7). Figure 5 shows particle size distribution of the utilized expansive soil.

Table 2. Results of basic shale properties tests.

\begin{tabular}{|c|c|c|c|c|c|c|c|c|c|c|c|c|}
\hline \multirow[b]{2}{*}{ Site } & \multirow[b]{2}{*}{$\begin{array}{c}\text { Sample } \\
\text { No }\end{array}$} & \multirow{2}{*}{$\begin{array}{c}\text { Water } \\
\text { Content } \%\end{array}$} & \multirow[b]{2}{*}{$\begin{array}{c}\gamma_{b} \\
\mathrm{~g} / \mathrm{cm}^{3}\end{array}$} & \multirow[b]{2}{*}{$\begin{array}{c}\gamma_{d} \\
\mathrm{~g} / \mathrm{cm}^{3}\end{array}$} & \multirow[b]{2}{*}{ USCS } & \multirow[b]{2}{*}{$\begin{array}{c}\text { Free } \\
\text { swelling (\%) }\end{array}$} & \multicolumn{3}{|c|}{ Grain Size } & \multicolumn{3}{|c|}{ Atterberg Limits } \\
\hline & & & & & & & Clay\% & Silt \% & Sand \% & $\begin{array}{c}\text { Liquid } \\
\text { Limit }\end{array}$ & $\begin{array}{c}\text { Plastic } \\
\text { Limit }\end{array}$ & $\begin{array}{c}\text { Plasticity } \\
\text { Index }\end{array}$ \\
\hline \multirow{3}{*}{$\begin{array}{c}\text { Gebel Al } \\
\text { Qurna }\end{array}$} & 1 & 6.29 & 2.20 & 2.06 & clay high plasticity & 110 & 68.70 & 28.30 & 3.00 & 50.90 & 19.19 & 31.71 \\
\hline & 2 & 4.96 & 2.18 & 2.08 & clay high plasticity & 136 & 63.80 & 31.20 & 5.00 & 54.13 & 22.79 & 31.34 \\
\hline & 3 & 5.77 & 2.21 & 2.10 & clay high plasticity & 150 & 62.75 & 35.00 & 2.25 & 55.20 & 22.11 & 33.09 \\
\hline
\end{tabular}

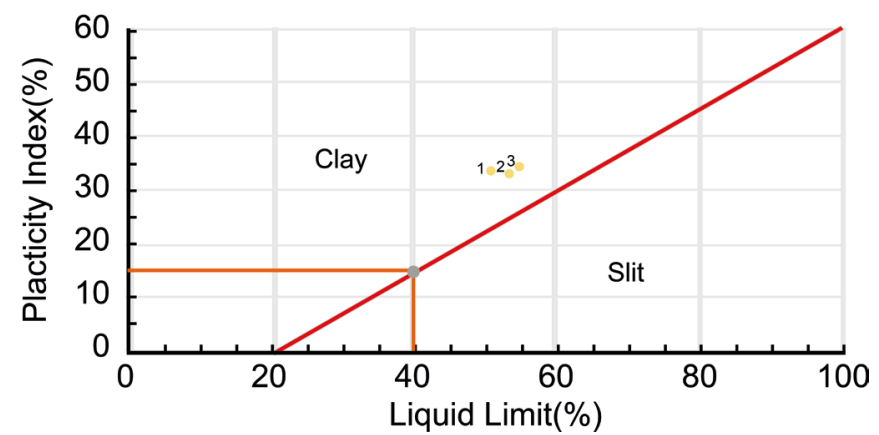

Figure 4. The textures of the shales according to Liquid limit and Plasticity index.

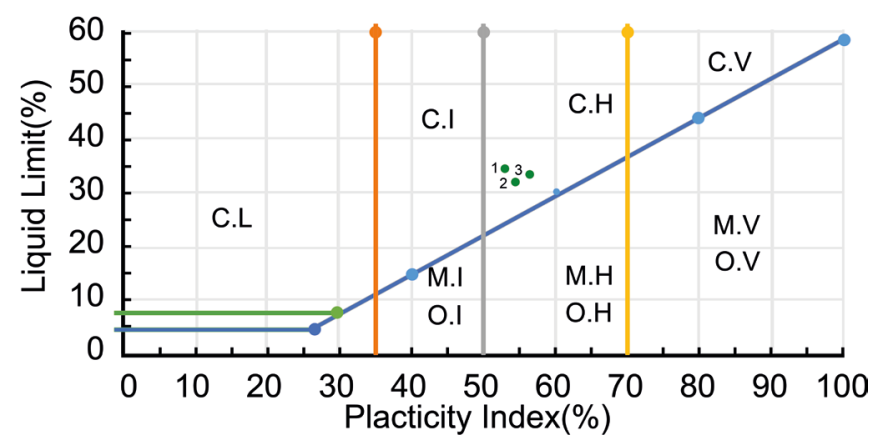

Figure 5. Particle size distribution of the utilized expansive soil. 
All the samples points plotting located in the high expansive clay zone of the diagram, Esna Shale as a destructive agent and its effect on heritage buildings and sites. The Esna Shale was classified as high expansive soil by many autho (Abdellah, Fathi, Abdelhaleem, \& Dewidar, 2018; Ayman et al., 2016; Cross, 2008; Ismail, Anderson, \& Rogers, 2005; Zeid, Attia, \& Abdellah, 2015; Wüst \& McLane, 2000). Figure 6 shows Unified Soil Classification System (USCS) in which the samples were found in high expansive soil according to Unified Soil Classification System (Hazelton \& Murphy, 2016).

\subsection{Swelling Tests}

Standard consolidometer was used to perform the swelling test. Many researchers have described two parameters to evaluate the swelling properties of expansive soils, which are swell potential and swell pressure. Swell potential is defined as the percentage increase in relation to the original height of the specimen, whereas the swelling pressure is designated as the pressure which is required to prevent the swelling of the sample.

\subsubsection{Specimen Preparation for Swelling Tests}

To study the magnitude of possible swelling in clay, simple laboratory odometer tests were conducted on remolded specimens. Swell potential tests and swelling pressure tests were considered the common testes for studying the swelling behavior of expansive soil. Remolded specimens were carried out at maximum dry density and optimum moisture content according to modified Proctor test. A circular mold (17 mm high and $50 \mathrm{~mm}$ in diameter) was used to produce soil specimens for swelling potential and swelling pressure tests. To obtain a shale specimen at a maximum dry density and optimum moisture content, a dry weight of the prepared soil, to fit the volume of the mould at the required density, was weighted and thoroughly mixed with the right amount of distilled water to achieve the prescribed moisture content. The moist soil was then placed in the mould and pressed by a hydraulic jack to exactly fit the mould. The mould was then disassembled to extract the soil specimen. The shale specimen gently placed

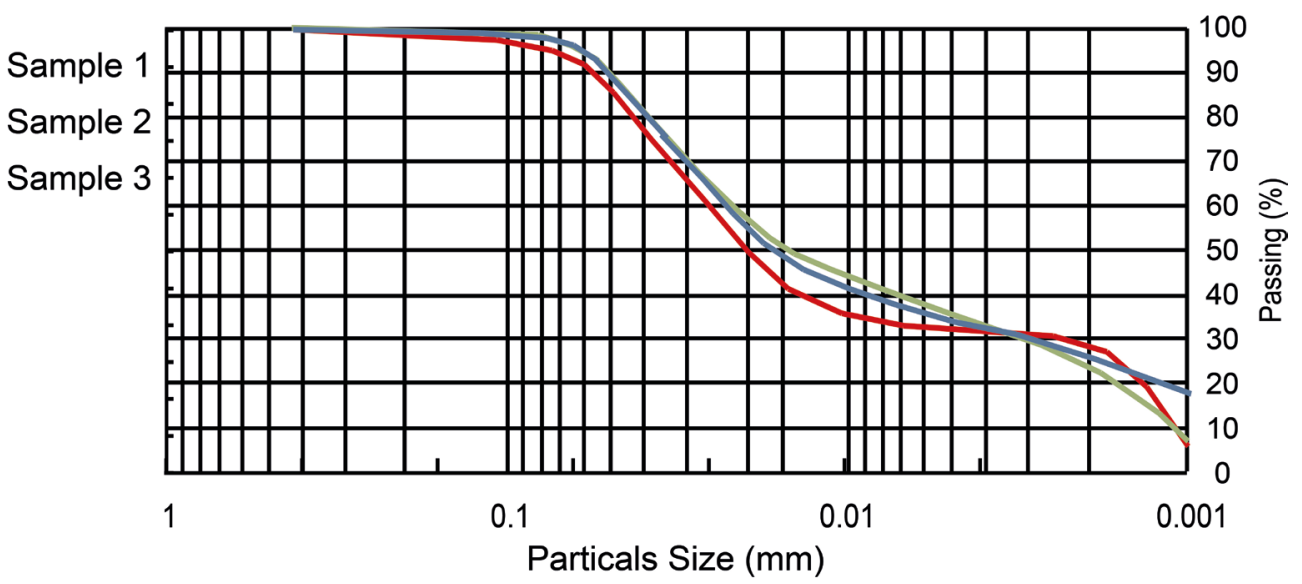

Figure 6. Unified shale classification system (USCS). 
over a porous stone in the testing ring. The ring was fixed with the clamp and the clamp was fixed to the testing cell by three screws. Another porous stone was placed on the top of specimen. The assembled cell was placed in the odometer swelling device and a small surcharge $(6.9 \mathrm{kPa})$ was placed on the soil specimen, and the dial gauge was set to zero (Guney, Sari, Cetin, \& Tuncan, 2007).

\subsubsection{Swell Potential Tests}

To conduct free swell test according to ASTM D4546 Method A, distilled water was poured into the odometer cell to start the test. The dial gauge readings were recorded at $0.25,0.50,1,2,4,8,15,30,60,120$ and 1440 minutes. By the end of a 24-hour period of time, all the tested specimens reached a state of no further swell activity with time. The percent free swell was calculated as the amount of swell (increase in specimen height) divided by the initial height of the soil specimen. To conduct the potential swell pressure test (ASTM D4546 Method C), distilled water was poured into the odometer cell to start the test. The soil specimen height was maintained constant (preventing swell of the specimen) by adding weight on the specimen just to keep it at its original height. The test was ended when there was no observed swell activity. The swell pressure was calculated as the amount of added load to maintain the specimen at its initial height divided by the area of the soil specimen. Figure 7 shows vertical deformation versus time at stress levels $6.9 \mathrm{kPa}$ for the studied soil specimens. Figure 8 illustrates vertical displacement versus stress levels for the studied soil specimens. From the two figures the expansive effect of the studied samples was clear.

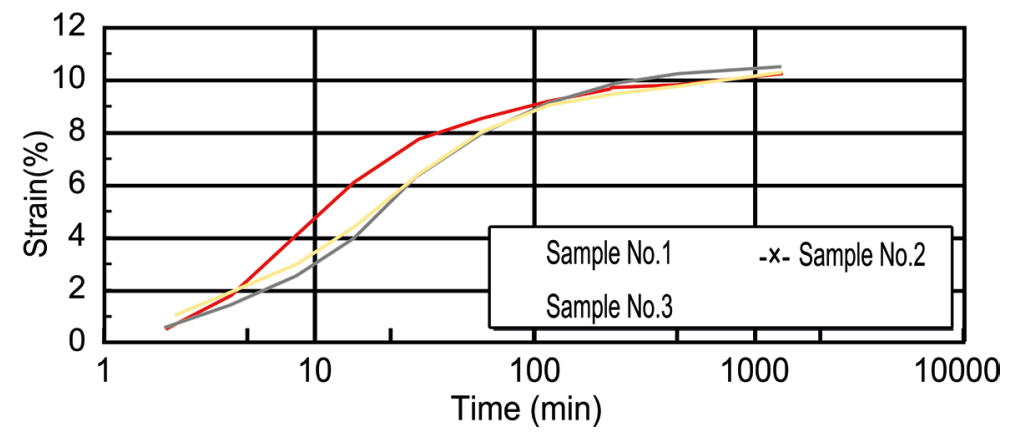

Figure 7. Vertical deformation versus time at stress levels $6.9 \mathrm{kPa}$ for study shale.

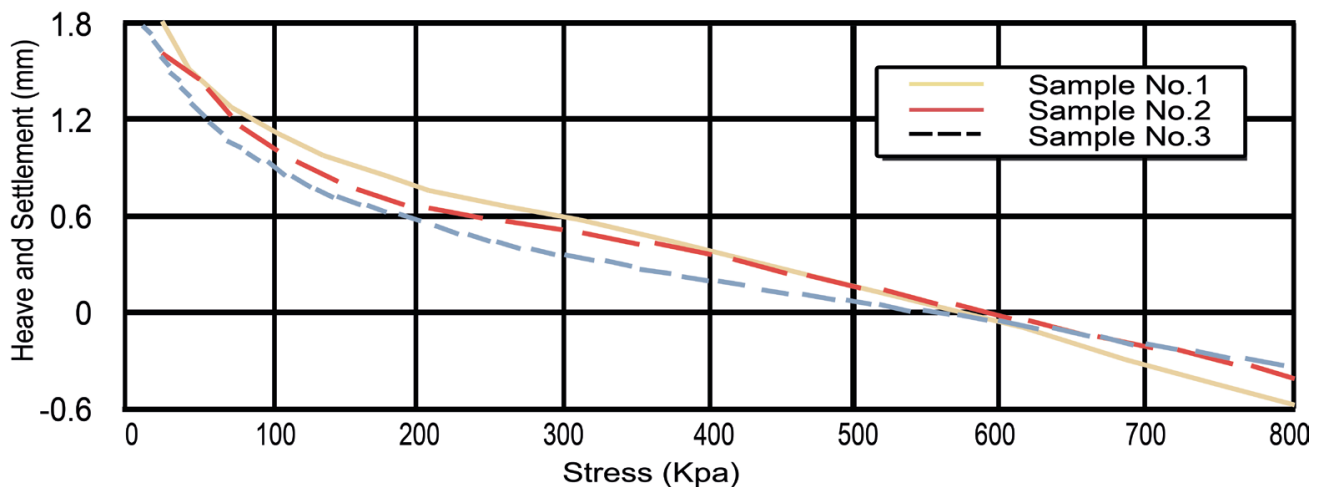

Figure 8. Vertical displacements versus stress levels for study shale. 


\section{Shale Classification}

Soil classification is an important aspect of laboratory tests, which describe the characteristic of the soil. There are different methods of classification based on the identification tests performed on the soil. These methods are discussed as follows:

\subsection{Classifications Based on Plasticity Index}

Plasticity index is a parameter which can be used as a preliminary indicator of the swelling characteristic of a soil. The following values were proposed by (Aiban, 2006) to relate soil expansively and plasticity index and showed in Table 3. Relating the plasticity index of the studied shales with the above given range reveal that the shales fall in the range of high swell potential. Dakshanamanthy and Raman (1973) put another classification system based on liquid limit and plasticity index as shown in Figure 6. According to this system, the studied shale samples of the studied areas fall in the range of high swelling potential. Figure 9 shows the studied samples are high according to classification chart based on liquid limit and plastic index.

Another way of identifying the expansive soil is to use the activity method quoted by (Chen, 2012). The proposed classification chart is shown in Figure 10 based on this classification the degree of soil expansion in study area is high. Figure 11 classification is based on the test using compacted specimen, percentage of clay and activity (Yilmaz, 2006).

\subsection{Classification Based on Swelling Potential}

Seed \& Lundgren (1962) proposed classification system for expansive soils according to the values of swell potential as shown in Table 4. According to this

Table 3. Shale classification based on plasticity index.

\begin{tabular}{cc}
\hline Soil Expansively & Plasticity index (P.I) \\
\hline Low & $\leq 15$ \\
Medium & $10-35$ \\
High & $20-50$ \\
Very High & $>50$ \\
\hline
\end{tabular}

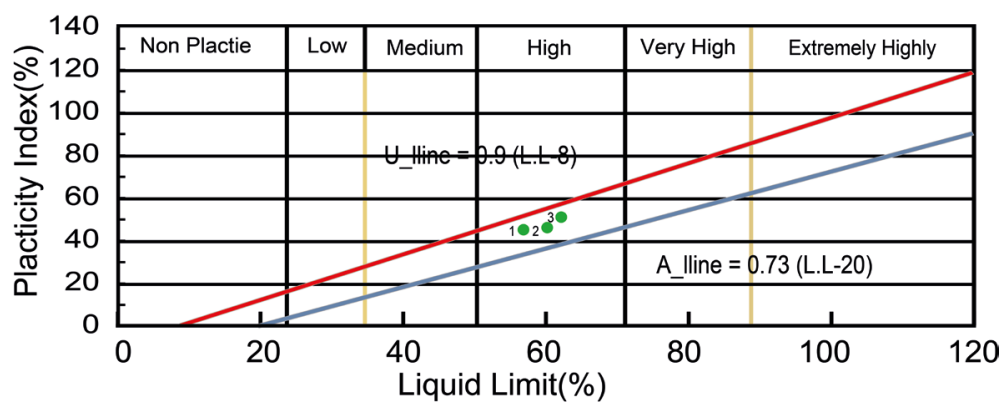

Figure 9. Classification chart based on liquid limit and plastic index. 
classification, the studied shales are considered as high expansion where the values of swelling potential range between $8.87 \%$ to $10.47 \%$.

\subsection{Classifications Based on Swelling Pressure}

The studied shales are highly expansive where the values of swelling pressure range between 550 to $600 \mathrm{kPa}$ Table 5 matched with the proposal classification system for expansive soils (Das et al., 2010)).

\section{Unconfined Compression (UC) Test}

The unconfined compression test is a special case of the unconsolidated undrained triaxial test. In this case, no confining pressure to the specimen is applied. The UC test is one of the easiest and simplest tests for determining a quick estimate of the shear strength of cohesive soils. The test provides an immediate approximate value of the compressive strength of the soil, either in the undisturbed or the remolded condition. It is also widely used to determine the consistency of saturated clays and other cohesive soils. The UC tests were carried out on 6 undisturbed samples obtained, by tube sampling, from the field. Details of testing procedures are given in California Test 221, March 2000. Place specimen on base of holder and set holder on compression device. Lower loading piston

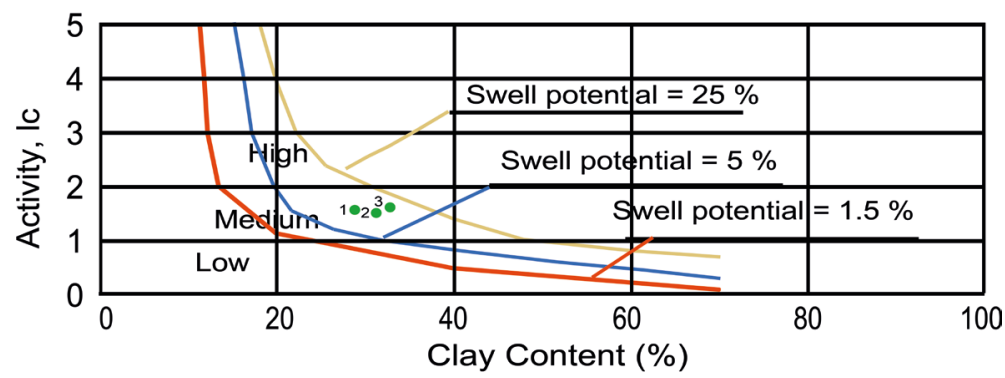

Figure 10. Classification chart based on clay content and activity.

Table 4. Soil classification according to swell potential.

\begin{tabular}{cc}
\hline Degree of Expansion & Swell potential \\
\hline Low & $0-1.5$ \\
Medium & $1.5-5$ \\
High & $5-25$ \\
Very High & $>25$ \\
\hline
\end{tabular}

Table 5. Soil classification of expansive soil according to swelling pressure.

\begin{tabular}{cc}
\hline Degree of Expansion & Swell pressure $(\mathrm{kPa})$ \\
\hline Low & $<196$ \\
Medium & $196-392$ \\
High & $392-687$ \\
Very High & $>687$
\end{tabular}




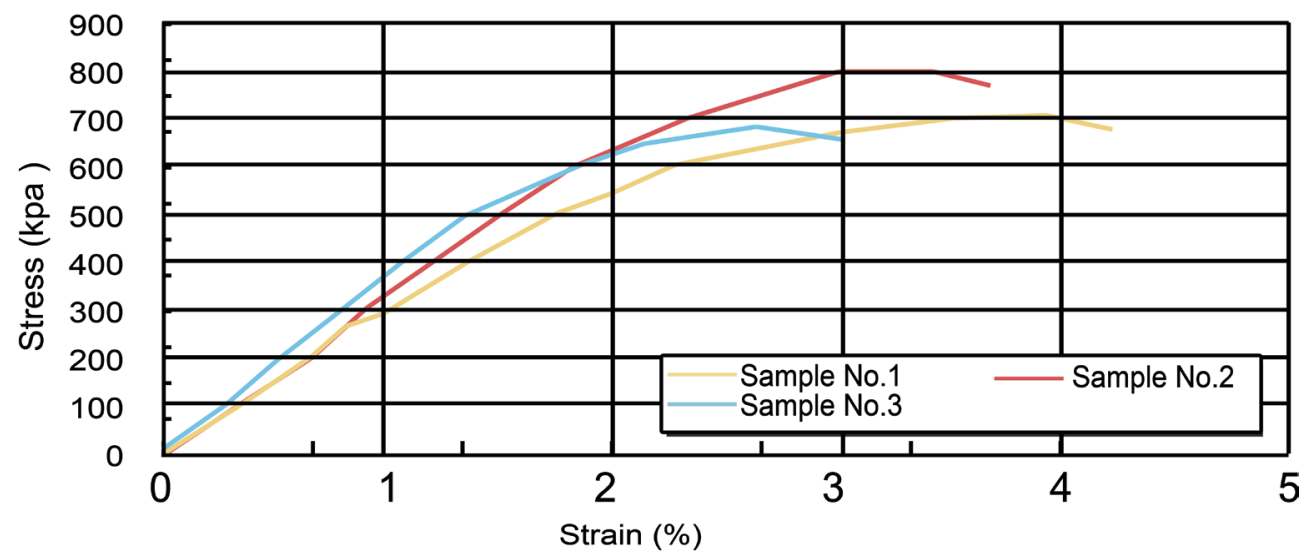

Figure 11. Relation between stress and strain of the studied shales.

until it contacts specimen push rod. Contact will be noted by slight reading on load readout gauge. Zero out readout gauge, check strain rate setting, and begin test. Continue test until load values decrease or until $20 \%$ strain is reached (Hemeda, 2018). The results of UC tests are shown in Figure 11.

\section{Conclusion}

The evaluation of expansive activity of Esna shale is a necessary to integrated conservation approach of heritage buildings especially where the expansive activity is high according to (a) Soil classification based on plasticity index, (b) Classification chart based on the liquid limit and plastic index, (c) Classification chart based on clay content and activity, (d) Soil classification, and (e) Swelling pressure. The deterioration varied between Amenhotep III, Habu and Hatshepsut temples. Amenhotep III was destructed completely. The flooding region, irrigation canals and agriculture activity which were surrounded by Amenhotep III Temple may be considered the main reason for raising the expansion activity of Esna shale, which resulted in complete damage for the mentioned temple.

\section{Acknowledgements}

A lot of thanks to Associate professor Dr., Mohammed Y. Abdellah (Mechanical Engineering Departments, Faculty of Engineering, South Valley University) for his support in engineering tests.

\section{Conflicts of Interest}

The authors declare no conflicts of interest regarding the publication of this paper.

\section{References}

Abdal-Hay, A., Hamdy, A. S., Abdellah, M. Y., \& Lim, J. (2014). In Vitro Bioactivity of Implantable Ti Materials Coated with PVAc Membrane Layer. Materials Letters, 126, 267-270. https://doi.org/10.1016/j.matlet.2014.04.048

Abdellah, M. Y., Fathi, H. I., Abdelhaleem, A. M., \& Dewidar, M. (2018). Mechanical Prop- 
erties and Wear Behavior of a Novel Composite of Acrylonitrile-Butadiene-Styrene Strengthened by Short Basalt Fiber. Journal of Composites Science, 2, 34. https://doi.org/10.3390/jcs2020034

Abdellah, M. Y., Gelany, A., \& Zeid, M. M. A. (2014). Compressive and Failure Strength of Sand Stone with Different Strengthen Materials. American Journal of Materials Engineering and Technology, 2, 43-47.

Abou El-Anwar, E., EL-Wekeil, S., \& Gaafar, S. S. (1819). Contribution to the Mineralogy, Geochemistry, and Provenance of the Lower Eocene Esna Shale in the Farafra Oasis, Western Desert, Egypt. Journal of Applied Sciences Research, 9, 5344-5345.

Ahmed, A. A. (2009). Land Use Change and Deterioration of Pharaonic Monuments in Upper Egypt. Journal of Engineering Sciences, 37, 161-177.

Aiban, S. A. (2006). Compressibility and Swelling Characteristics of Al-Khobar Palygorskite, Eastern Saudi Arabia. Engineering Geology, 87, 205-219. https://doi.org/10.1016/j.enggeo.2006.07.003

Ayman, M. M., Abdelhaleem, M. Y. A., Fathi, H. I., \& Dewidar, M. (2016). Mechanical Properties of ABS Embedded with Basalt Fiber Fillers. Journal for Manufacturing Science and Production, 16. https://doi.org/10.1515/jmsp-2016-0006

Chen, F. H. (2012). Foundations on Expansive Soils (vol. 12). ҐAmsterdam: Elsevier.

Cross, S. W. (2008). The Hydrology of the Valley of the Kings. London: Sage Publications.

Das, S. K., Samui, P., Sabat, A. K., \& Sitharam, T. G. (2010). Prediction of Swelling Pressure of Soil Using Artificial Intelligence Techniques. Environmental Earth Sciences, 61, 393-403. https://doi.org/10.1007/s12665-009-0352-6

Dupuis, C., Aubry, M. P., King, C., Knox, R. W. B., Berggren, W. A., Youssef, M., Roche, M. et al. (2011). Genesis and Geometry of Tilted Blocks in the Theban Hills, near Luxor (Upper Egypt). Journal of African Earth Sciences, 61, 245-267.

https://doi.org/10.1016/j.jafrearsci.2011.06.001

El-Bayomi, G. (2007). The Geomorphological Hazards in the Archaeological Area West of Qena Bend. Journal of Applied Sciences Research, 3, 175-184.

Guney, Y., Sari, D., Cetin, M., \& Tuncan, M. (2007). Impact of Cyclic Wetting-Drying on Swelling Behavior of Lime-Stabilized Soil. Building and Environment, 42, 681-688. https://doi.org/10.1016/j.buildenv.2005.10.035

Hazelton, P., \& Murphy, B. (2016). Interpreting Soil Test Results: What Do All the Numbers Mean? Chemin de Baillarguet: CSIRO Publishing. https://doi.org/10.1071/9781486303977

Hemeda, S. (2018). Engineering Failure Analysis and Design of Support System for Ancient Egyptian Monuments in Valley of the Kings, Luxor, Egypt. In M. Badr, \& A. Lotfy (Eds.), Sustainable Tunneling and Underground Use. GeoMEast 2018. Sustainable Civil Infrastructures (pp. 126-158). Cham: Springer. https://doi.org/10.1007/978-3-030-01884-9_10

Ibrahim, N. M., Rahim, N. L., Amat, R. C., Salehuddin, S., \& Ariffin, N. A. (2012). Determination of Plasticity Index and Compression Index of Soil at Perlis. Apcbee Procedia, 4, 94-98. https://doi.org/10.1016/j.apcbee.2012.11.016

Ismaiel, H. A., \& Badry, M. M. (2012). Geotechnical Evaluation of Sedimentary Rocks and Karstification Phenomena of Carbonates Exposed along New Upper Egypt-Red Sea Road, Eastern Desert, Egypt. Journal of Earth Science and Engineering, 2, 636.

Ismail, A., Anderson, N. L., \& Rogers, J. D. (2005). Hydrogeophysical Investigation at Luxor, Southern Egypt. Journal of Environmental \& Engineering Geophysics, 10, 35-49. https://doi.org/10.2113/JEEG10.1.35 
Mahmoud, H. M., Kantiranis, N., \& Stratis, J. (2012). A Technical Characterization of Roman Plasters, Luxor Temple, Upper Egypt. Mediterranean Archaeology and Archaeometry, 12, 81-93.

Mohammed, Y., Hassan, M. K., \& Hashem, A. (2014). Effect of Stacking Sequence and Geometric Scaling on the Brittleness Number of Glass Fiber Composite Laminate with Stress Raiser. Science and Engineering of Composite Materials, 21, 281-288. https://doi.org/10.1515/secm-2013-0038

Seed, H. B., \& Lundgren, R. (1962). Prediction of Swelling Potential for Compacted Clays. Journal of the Soil Mechanics and Foundations Division, 88, 53-88.

Temraz, M. G. M. A. (2005). Mineralogical and Geochemical Studies of Carbonaceous Shale Deposits from Egypt.

Wüst, R. A., \& McLane, J. (2000). Rock Deterioration in the Royal Tomb of Seti I, Valley of the Kings, Luxor, Egypt. Engineering Geology, 58, 163-190. https://doi.org/10.1016/S0013-7952(00)00057-0

Yilmaz, I. (2006). Indirect Estimation of the Swelling Percent and a New Classification of Soils Depending on Liquid Limit and Cation Exchange Capacity. Engineering Geology, 85, 295-301.

Zeid, M. A. A., Attia, M. A., \& Abdellah, M. Y. (2015). Study the Use of Recycled Aggregates in the Casting Shallow Foundations. International Journal of Advances in $\mathrm{Me}$ chanical and Civil Engineering, 2. 